\title{
AN INTEGRATED APPROACH TOWARDS SME RESTRUCTURING: TURKEY AND THE EUROPEAN UNION
}

\section{Klaus JURGENS ${ }^{*}$}

\section{Abstract:}

Europeanization has many aspects - talking about it has no value 'per se' as without a strong and sustainable economy, Europeanization means nothing to neither industry nor citizen unless it includes a wake-up call about how to make the economy technically ready for EU accession. SME, representing $99.8 \%$ of all Turkish companies, form the backbone of the Turkish economy. Foreign investors and companies may come and go Turkish SME will stay. This article tries to in the first instance bridge the gap between Business Administrative-related research and problems encountered by SME (Company Restructuring as tool to overcoming obstacles as currently faced by Turkish SME); it then takes a close look at how SME in EU countries (with Germany as case in point) over time embraced Europeanization as a chance, rather than perceving it as a threat; and moreover, analyses the potential for a comparative approach as application in both the Turkish, and European Enterprise Policy Making Domains. As research into the linkage between SME and Entrepreneurship is under-developed and under-researched not only in Turkey, the article promotes the case for establishing a novel University based Turkish SME Centre, while a future article highlights the Internationalization of such efforts under the umbrella of European Research for the Benefit of SME.

Keywords: Europeanization, Company Restructuring, SME in Turkey and Europe, Enterprise Policy, Competition

\section{$\ddot{O}_{z e t:}$}

Avrupalılaşmanın birçok yönü vardır. Eğer güçlü ve sürdürülebilir bir ekonominiz yoksa Avrupalılaşmaktan bahsetmenin bir anlamı yoktur.

\footnotetext{
${ }^{*}$ Lecturer, Faculty of Business Administration, Bilkent University.
} 
AB'ye girmek için ekonomide teknik olarak bir farkındalık yaratılmamışsa, Avrupalılaşmak ne sanayi ne de vatandaşlar için hiçbir şey ifade etmez. Türk şirketlerinin \%99,8'ini oluşturan KOBİ'ler, Türk ekonomisininin omurgasıdır. Yabancı yatırımcılar ve şirketler gelip gidicidir, fakat KOBİ'ler daima buradadır. Bu makale, ilk olarak KOBI'lerin problemleri ile işletmeye dayalı araştırmalar arasındaki bağılantıyı oluşturmaya çalışmakta (Türkiye'deki KOBİ'lerin hali hazırda karşılaştıkları engelleri aşmada kullanılması için bir araç olarak şirket yeniden yapılandırılması); daha sonra da Avrupa Birliği ülkelerinde (bu noktada örnek olarak Almanya) KOBİlerin Avrupalılaşmayı benimsemeyi tehdit olarak algılamaktan ziyade nasıl bir şans olarak kullanıldığı incelemektedir. Bununla birlikte makalede Türk ve Avrupa girişim politikası oluşturma ve girişim alanları üzerinde uygulanmak için karşılaştırmalı bir yaklaşımın imkanını incelemektedir. KOBI'ler ve girişimcilik arasındaki ilişki üzerine araştırmalar sadece Türkiye'de değil genel olarak yetersiz olduğundan bundan sonra yazılacak bir makale böyle bir çabayı KOBİ'lerin yararına Avrupa Araştırmalarının şemsiyesi altında uluslararası boyuta taşıyacak yolu gösterirken- bu makale Üniversite merkezli yeni bir Türk KOBİ Merkezi'nin kurulmasını da teşvik etmektedir.

Anahtar Kelimeler: Avrupalılaşma, Şirketlerde yeniden yapılanma, Türkiye'de ve Avrupa'da KOBİ'ler, Girişimcilik Politikası, Rekabet

\section{Introduction}

SME matter to each economy, but in particular to the Turkish economy. A comparative analysis is required to establish the State of the Art with regards to research into SME. It has to be an integrated approach. Furthermore, it should be anchored in a newly formed national SME Centre (which of course by definition must be cross-border in its approach). 'Integrated approach' implies that research into SME must include the option for establishing Best Practices about how to supporting them. Ultimately, integrated services for SME are a key to overcoming obstacles as currently experienced by Turkish companies. Integrated services are to be understood as the whole set of possible support mechanism that can be employed by SME to overcoming these obstacles. Integrated services for SME will play a more crucial role in Turkey once a network of Business

\footnotetext{
1 'Integrated approach' is a term used in a recent Call for Tenders about redesigning the network of European Info Centres. It refers to SME only.
} 
Support Centres has been set up (in continuation of the existing EIC). ${ }^{2}$ The same obstacles were experienced by European SME. Closeness of business graduates and advisers to the companies is a key factor, so is regional coverage. As with clustering, support mechanism for SME must be where the enterprises are. We can incorporate Porter and his approach towards economic geography (Porter, 2000). Reversely, enterprises should be where their customers are. The debate about SME support mechanism is re-visiting the argument (see Porter below) about whether Globalization has reenforced Localization. Not only is the proximity of SME support mechanism to the enterprises a success factor; should clustering become a tool to help SME overcome their obstacles, we would need to follow Porter as explained in the introduction to 'Clusters and the New Economics of Competition':

This article explains how clusters foster high levels of productivity and innovation and lays out the implications for competitive strategy and economic policy. Economic geography in an era of global competition poses a paradox. In theory, location should no longer be a source of competitive advantage. Open global markets, rapid transportation, and highspeed communications should allow any company to source any thing from any place at any time. But in practice, location remains central to competition. Today's economic map of the world is characterized by what Porter calls clusters: critical masses in one place of linked industries and institutions--from suppliers to universities to government agencies--that enjoy unusual competitive success in a particular field. The most famous examples are found in Silicon Valley and Hollywood, but clusters dot the world's landscape. Porter explains how clusters affect competition in three broad ways: first, by increasing the productivity of companies based in the area; second, by driving the direction and pace of innovation; and third, by stimulating the formation of new businesses within the cluster. Geographic, cultural, and institutional proximity provides companies with special access, closer relationships, better information, powerful incentives, and other advantages that are difficult to tap from a distance. The more complex, knowledge-based, and dynamic the world economy becomes, the more this is true. Competitive advantage lies increasingly in local things--knowledge, relationships, and motivation--that distant rivals cannot replicate (Porter, 1998).

\footnotetext{
2 'EIC' stands for European Info Centre, a network of support centres all across the European Union aiming in particular at SME.
} 
In other words, SME support mechanism including advice about clustering must be tailor made for a specific region and its problems (the 'proximity'), but as well focusing on opportunities.

SME support mechanism should in the first instance be based on a number of SWOT analysis. ${ }^{3}$ Practical experience has shown that in particular the first generation Turkish business owner can be convinced about the necessity for change when a SWOT is presented which summarizes critical points in laymen's terms. It must avoid jargon and should be written for the 'amateur professional', a term coined by John Courtney with regards to Business Plan drafting for SME (Courtney, 2006).

\section{The importance of SME}

The methodology employed is novel and innovative as it encourages SME to improve their technical readiness via company restructuring. It favors the setting-up of organizational structures specifically designed for SME (up until 250 staff) before embarking on expansion. It contradicts the assumption that $40 \%$ of Turkish SME will go out of business due to globalization and EU harmonization - the article argues the case that on the contrary, more sustainable SME can be established if 'competition' is understood and applied correctly.

The approach clearly links scientific Business Administrative research with requirements as presented by various Turkish and European industry sectors. SME restructuring does not copy large company restructuring which more often than not focuses on laying off staff. Family Business and SME need to tackle their problems by increasing skills and upgrading knowledge including existing employees, in particular about financing and export options. Turkish SME contribute only $26.5 \%$ to the overall value of the economy and $10 \%$ to total exports. They do amount to $99.8 \%$ of enterprises, though. This gap shows a number of problems which will be discussed now.

Whereas the headcount with regards to the current SME Definition has been harmonized for Turkey and the EU (Micro SME: less than ten staff, Small SME less than 50, and Medium sized SME up until 250 employees), the turnover threshold was capped at,25 mio YTL for Medium sized SME in

\footnotetext{
${ }^{3}$ A SWOT Analysis introduces and examines strengths, weaknesses, opportunities and threats. For SME owners and managers, it is the most widely accepted scientific tool as it puts complex matters not into diagrams or charts, but easy to understand textual context. Competition, or 'Rekabet Analysis' in the Turkish language, is one such context.
} 
Turkey, while 50 mio EURO are acceptable for Medium sized EU SME. Likewise, the maximum balance sheet limits are 25 mio YTL for Turkish SME, contrary to 43 mio EURO for EU SME (European Commission, 2005a).

According to TURKSTAT, and as as printed in the Negotiating Paper for the Screening of Chapter 20, Enterprise and Industrial Policy, prepared by ABGS on May 4th 2006 (ABGS, 2006), the above mentioned 99.8 percent (the number of SME as percentage of total enterprises in Turkey) constitute for 76.7 percent of total employment, 38.0 percent of total investments, but only for ten percent of total exports. Addditionally, Turkish SME only represent 26.5 percent of the total value which is added to the Turkish economy. The figures show a similarity when compared with the EU in so far as the 99.8 percentage apply there as well (when counting the number of $\mathrm{SME}$ as percentage of all enterprises in the $\mathrm{EU}=25$ ). However, the significant difference is the amount of value added by EU SME to the EU = 25 economy, standing at 56.9 percent when compared to the 26.5 percent valid for Turkish SME (European Commission, 2005b).

Does this underline that SME in Turkey are feeder-industry only? Can we derive information about the quality of Turkish products? What can we learn about the differing purchasing powers? Questions I shall try to answer in my article and analysis. Ultimately, Turkish SME will be measured against the same EU SME Definition thresholds, as even before a possible EU accession has taken place, the EU SME Definition will be applied accordingly. Already today, Turkish SME are defined according to the EU Definition for funding purposes under FP7, which allows a far greater number of Turkish SME to benefit from funding. The acceptance of the EU SME Definition including turnover and balance sheet for Turkish SME with regards to obtaining funding under the Seventh Framework Program of the EU (FP7) was confirmed by Berand Verachtert during an ITO Workshop in Istanbul. This will stimulate Turkish SME to participate more actively in FP7. SME will grow if they start managing growth (Verachtert, 2007). Coming back to one of my previously stated points, the acceptance of having to overcome obstacles, and the willingness to understand that markets will not disappear but grow, should be clearly explained to SME.

\section{Obstacles faced by Turkish SME}

The following selected obstacles, taken from a much longer list that is currently used as integral part of the first fully-fledged Turkish University SME Module, create problems for Turkish SME. Bilkent Faculty of Business Administration was the first Turkish University that offered a 
course about 'SME and obstacles in cross-border ventures' to both its undergraduate and MBA students. The author's own research has shown that this is still valid at the time of going to print. The SME module focusses on SME and their particular obstacles, whereas other courses tend to link Entrepreneurship with other topics. It would of course be beneficial to have more Universities embarking on the 'Research into the functionality of Turkish SME' - path. SME are largely feeder industry, much less so endproduct manufacturer. Obstacles include homemade problems such as not enough access to finance, an often unskilled workforce, environmental deficits and no advance preparation for the accession process with the EU. The dilemma here is that "with or without" accession (Arrow, 1996), domestic laws and regulations will change in line with the EU Acquis.

The problem for SME in Turkey (and to a lesser extent to those in the ten countries that joined in 2004) is the fact that because EU accession was not perceived as happening in the immediate future, most industry sectors did not prepare for eventual EU membership. It seems as if Turkish industry was waiting until the actual start date for the negotiating process will be announced. However, once it was announced, industry and SME in particular were left completely in the cold. This is not a dilemma SME can blame on the EU or the Government, but it is a homemade industry problem which can be summarized as 'no foresight'.

Even non-EU experts are aware of the fact that national laws have to change long before the membership is sealed as it is the pre-requisite for, and not a follow-up result of it.

Sector Impact Analysis (IA) and Regulatory Impact Analysis (RIA) about the costs and benefits of certain directives and decisions as well as regulations, should have been carried out in the early 1990s, not after having started the actual accession process.

Impact Analysis has to be understood as Industry Sector Analysis, whereas Regulatory Impact Analysis is carried out by the Administration (Jurgens, 2006). A recently much over-hyped topic, it is basically nothing more than to analyzing the 'before, during and after' - policy making scenario impacts and effects. It should include a 'before the before' - phase, however, i.e. analysing potential impacts long before actual policy making documents are prepared in its first version. Early in 2007 did the Prime Ministry of the Republic of Turkey announce its intention to make Regulatory Impact Analysis mandatory. Turkish industry still have not understood the relevance of preparing their own, industry based Impact Analysis to enter a policy making dialogue. The Acquis Communautaire is 
in principle, non-negotiable. Derogations are the exception, although not entirely impossible (Işik 2007). Of much greater importance is using sector based IA to show policy makers why certain sectors would need more time to adjust. The Government can then produce its own RIA having taken sector IA into account. Working the other way round is very disadvantageous for the industry, and in particular for the SME of a CC.

The topic introduced here points to another problem: Turkish SME lack the strategic vision European SME have acquired over the decades. Europeanization and Globalization simply forced European SME to adapt. Globalization is similar to the EU Acquis - it will not go away.

Of course one has to defend Turkish companies up to a certain extent, as EU SME grew alongside the Acquis, but current CC SME must 'swallow' 80000 pages at once. This furthermore explains options and limitations for importing Best Practices to CC! As example, 'Best Practices' form the backbone of the Twinning Scheme currently in place between Turkey as CC and selected EU MS. A Turkish Ministry asks for a response to a Fiche they circulate amongst the MS about a national policy making item the $\mathrm{CC}$ has identified itself. Experts from the MS then work in the CC. The scheme is only applicable to Administrative Capacity Building. ${ }^{4}$ What Turkish SME need, however, is not copying practices employed in other countries, but a unique, tailor made approach based on present day Turkish (industry) reality. The exceptions to this rule as presented in my paper are 'Competition' and 'Company Restructuring'.

It is expected that most SME relevant directives, decisions and regulations will enter into force during the upcoming two to four years. Health and Safety or the Working Time Directive are examples (Pereira, 2006). The simple fact that many SME will have to double their transportation costs due to the required replacement of at present overloaded lorries is another case in point. Environmental concerns will come in as expensive. In particular the environmental impacts shall be presented later on in this paper.

However, while not all obstacles can be removed (the change in regulations concerning overland transport of goods for example), they may be deferred. SME can be given time to prepare for the changes. It can not be expected to have Turkish SME change overnight (and neither did European companies in other candidate countries).

\footnotetext{
${ }^{4}$ The term 'administrative capacity building' refers to the on-going Twinning Scheme/Program between the European Union and EU Candidate Countries.
} 
SME support aims at keeping enterprises in business as well as directing would-be entrepreneurs into the right, profit making start-up direction. At this stage, I wish to introduce the UK Household Survey.

The United Kingdom Department of Trade and Industry (DTI 2003) published a survey about attitudes in the public with regards to establishing their own business. All integrated services, paired with Business Administrative related research, can only come to fruition when enough potential entrepreneurs exist in any given country. DTI separated Thinkers from Doers, and introduced the term 'Avoiders'.

According to their findings from the year 2003, $24 \%$ are the combined number for Thinkers and Doers; eleven percent are Thinkers, 13 percent are Doers, and 76 percent are Avoiders. Key considerations according to the DTI study are the following: Thinkers disagree that they are scared of being in debt, disagree that they avoid taking risks whenever possible, agree thet they often see success stories about running a business in the media, and finally, disagree that they would not feel confident speaking to a Bank manager about a loan. It shows that a relatively large number of the population hesitates to open up their own business. It seems that security concerns (job, income and others) have outperformed entrepreneurial spirit. One of the initial tasks for a novel SME Research Centre wuld be to analyze the level of intent (Thinkers) in Turkey, and which enterprise policy making areas could stimulate interest in establishing a company. Another focus could be whether self employment and company ownership reduces unemployment in real terms, or not.

\section{Company Restructuring from an SME perspective}

It is however wrong to only complain about the inflexibility of SME. When policies change, they need to be explained to the business community. On top of that, SME owners and managers have serious concerns and demands that need to be channelled. Restructuring Turkish SME means to give a perspective for initially the next six to seven years. This figure is based on the assumption that Turkish industry will be ready for $\mathrm{EU}$ accession by the time the next EU budget will be finalized (20132014). I am actually arguing that Turkey as far as her technical readiness is concerned will be 'EU ready' before the EU is ready to accommodate Turkey. A fast-track SME technical readiness could be achieved in even less time (three to five years, as long as the political willingness to financially support SME continues to grow). Assuming that real birth-rates of SME can only be measured after four years (two years until the break-even point is reached, one year to start making profit and another year to become a 
sustainable enterprise), we need to concentrate on two types of enterprises, i.e. companies that are already in business but face problems, and those that are potential or real, start-ups.

The average family business may have been set-up by a perfect entrepreneur who took calculated risks, but is not a long-term manager. SME need strategic vision which in most cases must be implanted making use of external advice.

The following example may help to explain the root of the problem: a 150 staff SME in the parts production sector of the manufacturing industry is most likely dependend on their buyer in the sense of periods of high and low production. Forecasting is very difficult, and dependency on one contractor makes changes impossible. Over time, problems arose and competition arrived. Production in Turkey is in many instances as expensive as in Spain. The location advantage alone does not support enough SME. In order to stay in business and to ultimately increase the profit margin, a restructuring is required that would help the SME to diversify its product portfolio by adding individual or collective research. The key question in most cases is "do we buy know-how" or can we develop it in-house? A combination is often the best solution. Phasing out licensing, phasing in R\&D. Keeping the parts production, but adding capacity for new products. All this requires a long-term forecasting and implementation of a management structure including a General Manager. 5

Out of many academic disciplines, Business Administration seems to be the most appropriate one for adding strategic vision to SME. Successful graduates will have learned the differences between large and small companies. They will know how to write a Business Plan for SME. Besides, they will be able to restructure a company not in the sense of laying off

\footnotetext{
${ }^{5}$ The author is using a number of 'Model SME' during the MAN 473 SME Classes at Bilkent University. The model SME is positioned halfway through the current Turkish SME Definition: 150 staff, 12.5 million YTL turnover, 9.5 million YTL balance sheet, parts production or end-product and not as yet involved in export. The sectors we analyze are Healthcare, Food Packaging for take-away food, and TV-related parts (not the TV technology as such). A fourth case study is Organic Food (Tea). While the cases are taken from the authors personal expertise having worked as SME Consultant before returning full-time to a teaching position at University, all clues about location or actual company are removed for privacy reasons. MAN 473 is based on bringing Turkish SME reality into the classroom, while preparing graduates to carry sound academic advice and strategies to the SME community. Company Restructuring is the keyword here.
} 
staff, but ideally improving skills and knowledge of the existing employees They will, however, have to make crucial decisions about which sector should stay in, and which would better go out of, business. A vital elemen is introducing economic forecasting to the SME. Forecasting for SME is a totally different matter when compared with larger companies or family business in general. Many family business have long outgrown the SME Definition thresholds. Hence, I employ the term SME only, for the specific purpose of this analysis.

All this requires knowledge about where to get the funding from. In other words, it requires knowledge about Financing.

\section{The Four Freedoms and the Single European Market ('Europeanization: from obstacle to opportunity')}

European SME faced the same obstacles as Turkish SME currently face. Rural economies had to be transformed, urban development increased and new technologies were initially seen as something only the Americans or Japanese can muster. Export was evaluated as too risky. Cross-border tendering was basically unheard of. Unless having personal contacts with the Bank manager, large scale loans were impossible. But then change arrived and matters changed. Access to information and knowledge was the key. Not only this, the fact that a common market was created helped to internationalize European SME.

What was at first perceived as a threat (and in some instances is still today - the infamous example of the Polish plumber invading France is the most recent example -), was transformed into adding opportunity. While 12 or 15 competitors may sell into your market, you have acces to 12 or 15 new markets as well.

SME changed and restructured. Companies adapted to operate like an Organization. New positions like HR Manager, R\&D Manager or International Trade Manager were added.

The Four Freedoms refer to a Concept Paper that was published in 1985 (EU Commission, 1985) by the then Commission of the European Communities (referred to as EU Commission or European Commission today). While free movement of goods already formed a central part of the Customs Union, not before 1985 had the administrative body in charge of implementing EU Policies established a clear link between the free movement of goods, people, capital and services. Hence, the Single 
European $\mathrm{Act}^{6}$ was used to highlight besides other points, the submerging of the Four Freedoms under a 'single' Market. Initially, not much positive echo was heard in both the business communities as well as European Governments. Opening borders (in particular economic ones) was perceived as a non-priority at best, a threat at worst. The ongoing debate about the liberalisation of one of the four freedoms, i.e. Services, is case in point. Still today, we do not have a 'single' market if we would take the definition as outlined in the SEA of 1986 and the before mentioned Commission working paper from 1985, as reference. Over time, and with perseverence, did the fact that economic and physical borders have indeed been removed, enter the public and business conscience. European SME faced great economic dificulties in their respective countries, and only because the single market promised exactly what it said, an increased marketplace, was it possible to convince the business community that trade by definition must be without borders. As not enough goods were sold within one single country, opening up markets without restrictions was accepted as tool to increase profit margins or to put more bluntly, to stay in business first of all.

However, as mentioned earlier on, the Customs Union already made EU trade in principle, borderless. The new dimension was that after the SEA, the $\mathrm{EU}$ took most of the actual policy making on board, and this in particular affected SME in all member states. A shifting of decision making power from the nation state to the EU, including Enterprise and Industrial Policies, formed the backbone of an emerging single market in its true meaning. Nevertheless, up until today, and 20 years later, taxation is still a domestic matter (Corporate tax as example). Services are far from liberalised. Other examples spring to mind. The reason for introducing this point in great detail is twofold. Firstly, policy making documents as such do not change anything with regards to SME policies. Secondly, only when decision making power is clearly attributed to one or more transnational Authorities, can European companies start preparing effectively for the medium term.

Today, Turkish SME face the same challenge as European SME experienced 20 years ago, experience the same difficulties and ultimately, will overcome them. Europeanization as such is no threat. Lack of knowledge about it is.

${ }^{6}$ SEA is the abbreviation for the Single European Act. 
Going to rural regions in the enlarged EU, one witnesses the same problems as faced in rural parts of Turkey. Most people speak only one language. E-commerce is not as yet widespread (often unheard of). But foreign products have found a safe place everywhere, from the supermarket to the DIY (Do it yourself - store). Opening up markets lets the consumer decide. Prices can not skyrocket as purchasing powers determine the ultimate pricing of a product.

SME have acquired a very positive image in most European countries due to the fact that most EU member states have a functioning middle class system. By saying this I simply say that as a majority of citizen feels being part of the 'middle strata or class' of society, they value entrepreneurs who come from the same background. The German word 'Mittelstand' is the best description of and for this situation. 'Mittelstand' does not describe the actual citizen as part of the middle class, but introduces the family business per se as part of 'being in the middle', hence acceptable. The official term would be 'mittelstaendische Wirtschaft'. It has a much more positive connotation, then let's say, 'SME'?

\section{The value adding chain for SME}

Any start-up and all restructured SME need to fully understand the importance of the value adding chain. From the original start of the production to the final price including VAT, a precise calculation has to be made that weighs the options for each existing or new product, compares the maximum value scenarios and helps SME to go cross-border. One such element is analyzing differing VAT rates in EU countries as a zero rate market not necessarily means better sales and profits. The most important tool to introduce serious forecasting from day (and product) number one is using 'The value adding chain'. Although it includes VAT at all relevant stages, it is not about VAT (CBI, 2005). Each cost segment makes the product more expensive, and the costs must be offset in order to achieve a

7 'Mittelstand' here refers to describing business people who are situated inbetween the single entrepreneur and larger companies. It is a word that comes from the German language, linking middle class with business activities. 'Stand' would refer to your position in the societal hierarchy. 'Mittelstand' includes nonentrepreneurs, while 'mittelstaendische Wirtschaft' focuses on middle-class (not big - not small) company owners and entrepreneurs. However, over the decades the German Mittelstand embraced the competition: 'Konkurrenz belebt das Geschaeft', meaning 'Competition brings more business to your business'. A vital development Turkish SME must learn about as quickly as possible. Europeanization was the driving force behind this development in Germany and other European countries. 
sustainable profit margin. However, as the product becomes more expensive ('costly'), it acquires more value. It does in fact add value threefold: first of all, the company producing the good or delivering the service achieves a higher end price and hence, turnover. The economy benefits as SME add more value to it. Finally, the consumer benefits as the product will be of better quality and functionality. This model only works well once applied correctly. SME can not aim at achieving the hightest price possible in markets where purchasing power is limited. In order to understand markets, SME must undertake a Market Structure Survey which can be very costly. SME must professionalize their approach towards pricing and costing. This can not be done by individual SME. Sector associations should take this role on board and furnish their members with annually updated (EU and further afield) market entry data. Each step requires a separate analysis as indicated below.

Once all steps have been carefully laid out, the crucial question of VAT comes into play. A zero rate VAT market (for example for Books in the United Kingdom) does not necessarily mean that paper is a good product to be sold into the UK market (EU Commission, 2006d / EU Commission 2002). Assuming no trade restrictions apply, we must analyze why there is not VAT on Books. Is it because of a declining readership? Is it because the Government wants to encourage children to read more? Is it because the industry sector lobbied successfully to reduce the rate? For how much can we sell our paper, is the market saturated? For how much do end-users buy end-products, are books cheap or are they only cheaper in relative terms? What kind of paper quality is used in Books in our zero - rate VAT market? The list is still not exhaustive. It underlines, however, that the average SME in Turkey will not have sufficient access to all relevant data. Even if they do, they would not be able to analyse them correctly.

What is here introduced as a threat, however, is ultimately the only option to go into, or stay in, business. A threat can become an opportunity. The keyword is 'embracing the competition'. Better and more varied products, quality assured and sold in a number of markets are one solution. Turkish SME must approach competition as a positive factor. While competitors come to Turkey, Turkish SME can look, and go cross-border. Not only restructured, technically ready' SME will survive. Many classic sectors of the economy including micro business will benefit from a generally speaking stable economic climate. The aim is to bring as much knowledge to all SME, including e-commerce and e-tendering. 


\section{Why the SME Exit Strategy should be the SME Survival Kit}

Finding funding for SME is a crucial step in staying in business anc starting the required company restructuring process. Not only existing companies will benefit from better access to money, but potential start-ups as well. While in most European countries a relatively solid pool o financing instruments for SME exists, in most $\mathrm{CC}$ including Turkey finding sufficient funding for the preparation (seed), the start-up phase or the way to expansion and growth is difficult to say the least. When we combine this with a reluctance in general to go into debt, we are faced with a combination of potentially problematic obstacles. Integrated services must bring knowledge about available financing tools to the SME, while monetizable, business-administrative based advice will help to establish links and draft the most important dcument in this chain, a Business Plan tailor made for the needs and requirements of SME.

Why do SME Business Plans differ from other business plans, and which parts differ? SME have a break even point which kicks in relatively early, i.e. after only two years. Assuming that most SME do not have sufficient capital to survive after these initial 24 months, investors would be very hesitant to agree to lend larger amounts of money if the break even point is forecast to be much later than the accepted two-year SME average. A Business Plan for SME must show that the first serious profit will be obtained after 24 months. The SME then has another 12-24 months to come to a sustainable profit margin. Most SME would be considered as sustainable having a profit margin of around seven to eight percent. Hence, we can measure the real-birth rate of SME by giving them 48 months to have stabilized. The way to measure stabilization is by measuring the profit margin.

SME have to face greater volatility with one exception: in most instances, staff will have worked for the same entrepreneur for a considerable number of years (existing companies). In all other instances, SME are dependend on external factors most often outside their own control. From inflation to exchange rates to corporate taxation to changes in the VAT, as well as being dependent on a limited number of buyers who very often have an exclusive relation with their supplier SME.

Going into end-production 'or diversifying the product portfolio would help to ease the level of dependency, but would still not abolish the above mentioned external factors. Less turnover means less assets, and less assets mean less security for potential investors. Its a vicious circle SME must break free of. 
Another critical point is that every good SME Business Plan requires a comment about the Exit Strategy. This is easily understood by the second generation, but not necessarily fully embraced by the owner/first generation. Even SME who have successfully restructured including a General Manager position (required for all SME from 150 staff onwards), still depend on the owner/family. SME as parts of larger multinational hodings form not part of my analysis. Althoug they may have less than 250 staff, their headcount and balance sheet will in most cases not fit in with the by now EU wide accepted SME Definition.

Exit Strategy is the point in your companies history where you feel it is ready to being sold or publicly listed. An Exit Strategy is a key tool in convincing would-be investors that you yourself as company owner or entrepreneur want to make as much equity as fast as possible in order to reinvest. This in turn means the investor has a reduced risk level, as you and him pull and move into the same direction.

Does this mean that Integrated SME Services lead to a sell-out of Turkish SME once the exit strategy date has come? Do we only restructure SME to ultimately, sell them? Before answering these questions in my conclusions, I need to introduce two further chapters.

\section{Chapter 20 of the Turkish EU Acquis Communautaire}

Chapter headings and numbers change from time to time. For our purposes, the initial numbering was incorporated. Hence, we talk about chapter 20 (ABGS, 2006) which has Enterprise and Industrial Policies as topics. The Acquis Communautaire does not have a separate chapter on SME. What is often misinterpreted is the fact that topics affecting and impacting SME are to be found in various chapters. The chapter on Free Movement of Goods is a good example (which is separate from chapter 20). Chapter 20 in its original format distinguishes between industrial policies and enterprise policies. Enterprise policies relate to the general framework under which SME can operate. It includes linkages to the quantifiable targets in and of the Lisbon Objectives. The chapter outlines the basic guidelines under which SME can be set-up, grow and expand, and the funding mechanism abailable and above all, the new SME Definition. The web portal of the EU Commission heralds SME as important to the EU economy. Chapter 20 is the second chapter that was opened during the Turkish EU accession talks, assuming that similar to Research and Development, no serious roadblocks are to be found. Hence, no benchmarks were set. An 'easy' chapter however does not mean that SME do not face 
obstacles during the accession process. We must put chapter 20 into context. It has to be seen and examined in a comparative light.

\section{SME start-up and growth conditions in general}

A successful preparation for either Business Administrative related support, or indeed an industry sector impact analysis must first of all dismantle the Acquis, and then re-assemble it in the sense of analysing all 35 chapters. In nearly all Acquis chapters can we find obstacles EU SME had to overcome, while Turkish SME must still approach them.

Besides the Acquis Communautaire, the following points form part of an integrated approach. 1: Start-up conditions: Start-up conditions are interpreted as reducing red tape, streamlining taxation and coming to conclusions with regards to cross-border company structures (EEIG as only one such example). ${ }^{8}$ 2: Access to finance: Access to financing for young entrepreneurs must be enhanced. Both, point number one and two are underlining the importance of increased levels of funding for would-be entrepreneurs. 3: This leads to generally speaking, providing a favourable, profit-making oriented business environment. 4: SME must accept the fact that after company restructuring they will be measured against their effectiveness in the economy. 5: Having said all this, a key obstacle which must be solved jointly by Governments and SME are the environmatal impacts. The key question is: How to provide integrated services with regards to helping SME to overcome environmental hurdles? They can not be deferred for ever, but postponed to make certain Turkish SME know about the EU environmental legislation, have the support to start implementing it, and the assurance that both Turkish Government and EU give five to eight years before compliance is demanded. As TURKSTAT assumes there are 1.720.598 SME in Turkey (data from the year 2003), the investments required can reach 60 billion EURO. Fines for SME can reach six million YTL. Ministry Undersecretary Sarıkaya said in the Turkish Daily News (Sarikaya, 2007) that "European SMEs had realized that shortterm costs were small compared to long-term benefits". Knowledge about the Acquis chapters, about what to do when, and from where to get help for funding are key aspects of an integrated SME support structure. Pointing the finger is no option, giving advice is required!

\footnotetext{
${ }^{8}$ The European Economic Interest Group, or abbreviated EEIG, is one tcol with which to overcome cross-border obstacles SME are confronted with at present. See: Feasibility Study of a European Statute for SME, p. 9
} 
Examples that require urgent attention from the viewpoint of Turkish SME are: Hazardous waste, packaging materials, labelling, use of chemicals, transportation, air pollution, and energy consumption to name but a few.

\section{Conclusions}

Turkish SME can overcome the obstacles. Europeanization can be transformed from threat to opportunity. Turkish SME can embrace competition. Cross-border ventures are not limited to EU related trade; Turkish SME are very well positioned to approach markets to the east and southeast of the country. Business administrative related research, to be manifested in a novel SME Research Centre at a leading Turkish University, are key steps in firmly establishing SME and Entrepreneurship as both research topic, and tool to helping Turkish SME to overcoming the obstacles experienced due to Globalization and Europeanization. 


\section{References:}

ABGS (2006). Screening Chapter 20: Enterprise and Industrial Policy, Agenda Item III: SME and Enterprise Policies, Country Session: The Republic of Turkey, May 4th-5th 2006.

(2007). EU Accession Negotiations, Screening Process, (as published on the ABGS website www.abgs.gov.tr, English version, Turkey - EU Relations, Screening Process), March 13th 2007

Arrow, Kenneth J., The Ten Arrow Principles (1996), as printed in: Kovacsy, Z., and Orban, K., Regulatory Impact Analysis - A Comprehensive Approach - Summary, (November 18th 2005), Ministry of Justice, Department of Impact Analysis, Deregulation and Registration of Law, Republic of Hungary.

CBI, Centre for the promotion of imports from developing countries of The Netherlands (2005). EU Market Survey 2005, Organic Food Products.

Courtney, John (2006). Introduction to Business Plan Drafting, Beer and Partners, www.beerandpartners.co.uk, UK

DTI (Department of Trade and Industry) (2003). Small Business Service, NOP Social \& Political, Household Survey of Entrepreneurship 2003, Executive Summary

European Commission (2006), VAT Rates applied in the Member States of the European Community, Situation February 1st 2006, DOC/1803/2006-EN, DG Taxation and Customs Union, Tax Policy, VAT and other turnover taxes

(2005a), The new SME definition - User Guide and model declaration, Enterprise and Industry Publications, European Commission, www.europa.eu, in effect as from January 1st 2005

(2005b), Commission Staff Working Paper, The activities of the European Union for small and medium-sized enterprises: SME Envoy Report, SEC(2005)170, February 8th 2005, p. 8

and modernisation of VAT obligations for the European Commission (2002), PriceWaterhouseCoopers

Market, COM (85)310, 1985 
Feasibility Study of a European Statute for SME(2003). AETS, Contract letter No FIF 20030950, Study financed by the European Commission.

Işik, S. (2007). Guest Lecture at Bilkent University (MAN 473), April 19th 2007

Jurgens, K. (2006). Why Regulatory Impact Analysis can Overcome Obstacles Turkey Faces on her Way to Europe?. Insight Turkey, Vol. 8/3, www.insightturkey.com

Pereira, F. (2006). Analytical examination of the acquis communautaire, Working Time Directive. DG Employment, Social Affairs and Equal Opportunities, Unit D2 - Labour Law and Work Organisation, European Commission

Porter, M. E. (2000). Location, Competition and Economic Development: Local Clusters in a Global Economy. Economic Development Quarterly, Vol 14, No. 1.

(1998). Clusters and the New Economics of Competition. Harvard Business Review, November-December 1998

Sarıkaya, H.Z.(2007). Undersecretary Turkish Environment and Forestry Ministry, February 22nd 2007, as quoted in: SMEs fail to clear environmental hurdle, Turkish Daily News

Verachtert, B. and Niehoff, J. (2007). Research for the benefit of SME. EU Commission Brussels, as presented at a KOBİ Workshop organised by TUBITAK at ITO, Istanbul on February 14th 2007. 